\title{
CORRECTION
}

\section{Correction to: Breast cancer cell motility is promoted by $14-3-3 \gamma$}

\author{
Emiko Hiraoka ${ }^{1}$ (D) Takahiro Mimae $^{1} \cdot$ Masaoki $_{\text {Ito }}{ }^{1} \cdot$ Takayuki Kadoya $^{1} \cdot$ Yoshihiro Miyata $^{1} \cdot$ Akihiko $^{\text {Ito }}{ }^{2}$. \\ Morihito Okada ${ }^{1}$
}

Published online: 29 March 2019

(c) The Japanese Breast Cancer Society 2019

\section{Correction to: Breast Cancer}

https://doi.org/10.1007/s12282-019-00957-4

The correct name of the corresponding author should be "Takahiro Mimae", and not "Emiko Hiraoka"' as given in the original publication of the article.

Publisher's Note Springer Nature remains neutral with regard to jurisdictional claims in published maps and institutional affiliations.

The original article can be found online at https://doi.org/10.1007/ s12282-019-00957-4.

\section{Takahiro Mimae}

tmimae.0907.surgery@gmail.com

1 Department of Surgical Oncology, Division of Radiation Biology and Medicine, Graduate School of Biomedical and Health Sciences, Hiroshima University, 1-2-3 Kasumi, Minami-ku, Hiroshima City, Hiroshima, Japan

2 Department of Pathology, Faculty of Medicine, Kinki University, Higashiōsaka, Japan 